teaching and most of the research in this subject has been done in the college laboratories and cellars of Balliol, Trinity and Jesus Colleges. A fine spirit has been shown there and excellent work done-more, perhaps, than in many a university department with proper staff and ungrudged grants for material. But college laboratories are now at best makeshifts, rich only in improvisation. They are neither well endowed nor well equipped. They are small; not everyone is free to enter them and work there.

A new University building properly equipped and endowed is imperative, and it is fitting that Prof. C. N. Hinshelwood, who has succeeded Prof. Frederick Soddy as Dr. Lee's professor of inorganic and physical chemistry and is a leader of physical chemistry, should have as his place a proper official laboratory in which scattered researchers in this subject, collected from various parts of college and University buildings, may find a home. It is proposed to put up the building in the next four or five years in the Parks next to the Organic Chemistry Laboratory, if funds earmarked for it are forthcoming.

These are the immediate needs. Next comes that of the Physiology Laboratory, which some day must be rebuilt. It was originally put up in 1884, and the recent growth of the medical school must soon make change in it very desirable. Something also should be done to endow the Museum of the History of Science. A donor who might jib at seeing his comparatively modest contribution swallowed up in the general total might like to individualize it by helping this institution, which does good work on an exiguous income. It saves for the studies of future generations apparatus and other objects of historical value which might easily be lost in the midst of change.

Mention must also be made of the need for an extension of the Ashmolean Museum and for funds for archæological research, and, what is likely to be of far-reaching significance in the future, for research in the study of human society, social studies and allied subjects such as anthropology.

It is announced that the appeal has already produced a response averaging $£ 2,000$ a day. The promotion of the welfare and influence of the University of Oxford is worthy of the support of all who are concerned for the progress of learning in the present somewhat distracted state of world affairs.

\title{
Inter-Imperial Co-operation in Scientific Research
}

$\mathrm{A}^{\mathrm{s}}$ $S$ already pointed out in the leading article in NATURE of November 7 last (p. 777), the proceedings of the British Commonwealth Scientific Conference were mainly concerned with interImperial co-operation in supplying bibliographical information on the sciences relating to agriculture. Co-operative research in certain subjects was, however, suggested by various delegations from the countries represented. Sections of the report of the proceedings recently issued (Cmd. 534l. London: H.M. Stationery Office, 1937. 1s. 3d. net) deal briefly with such subjects of wide Empire interest as the transport and storage of foodstuffs, the control of insect infestation of stored products, the properties and utilization of wool, the collection and maintenance of plant material for crop improvement, and the control of damage by termites.

The Conference recommends that the contributions of overseas Governments to the Food Investigation Board of the United Kingdom should continue to be a matter for arrangement between the individual Governments interested in the transport and storage of foodstuffs, and that Governments should continue, pending further consideration, the payments they are making for work on wool at the Wool Industries Research Association's station at Torridon, Leeds. It also recommends that the Farnham House Laboratory of the Imperial Institute of Entomology be continued on an inter-Imperial basis by the countries interested in the control of insect pests by the use of parasites of these pests (so-called 'biologic control'), so as to maintain a small nucleus staff. Additional staff to deal with specific problems will be paid for by fees as occasion arises. Though stating that this method of controlling insect pests is still in its infancy, no reference is made to the need for research into it ; the aim is to bring the cost of maintaining the Laboratory into close relation to the specific (applied) services demanded of it.

Similarly, in considering the work-largely pioneer work-on the control of insect infestation 
of stored produce carried out at Slough at the Stored Products Research Laboratory of the Imperial College of Science and Technology, the Conference, while recording its appreciation of the work, notes that in future the contributions from Empire countries towards general expenses will cease, and special inquiries will be paid for by fees ; no inter-Imperial finance for research on this subject is suggested. No recommendations for financial co-operation on the various other subjects of wide interest discussed were made, beyond those included in the provision of bibliographical services and in the identification work of the Institutes of Entomology and Mycology.

Co-operation in scientific research, jointly financed on an inter-Imperial scale is, at the moment, in abeyance. It seems likely to remain so until its scope can be more clearly defined by the men of science concerned, and its planning entrusted to them.

\section{Birds of the Greek Classics}

\section{A Glossary of Greek Birds}

By D'Arcy Wentworth Thompson. (St. Andrews University Publications, No. 39.) New edition. Pp. viii +342 . (London: Oxford University Press, 1936.) 12s. $6 d$. net.

$\mathrm{T}$ HE first edition of this book was published forty years ago, and the author tells us that it is fully fifty since he began to write it. It is the work of a Greek scholar of wide knowledge and immense reading, as well as an expert naturalist. More, much more, than fifty years ago, he says in his preface, his father taught him that many a Greek word or name of a hero was foreign to Aryan speech. The merchant and the mariner had brought strange words home from overseas, and many a beast and bird and hill and river had kept its pre-hellenic name. Many old names of birds and fish are recorded by Italian scholars from the rich dialects of Italy, and new light is thrown hereby on obscure Greek and Latin words.

The author quotes in his preface a series of names of birds with strange non-Greek (probably Phœnician) names which, save one exception, it is difficult to identify with their present modern Greek names, or even to prove by their

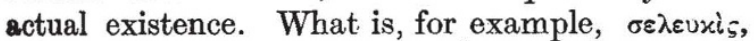

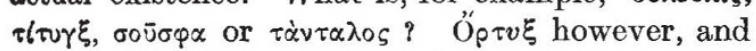
$\pi \varepsilon \varepsilon_{0} \delta \xi$, differ very little from their present names and the foreign traveller who would designate them, as many of the other Greek birds, by their ancient name to a Greek peasant would be easily understood by him-unless the pronunciation was the Erasmian one or his accent too foreign.

So far as I can judge, the glossary of the names of birds in the book seems to be very complete, and the reader is amazed by the profusion of quotations from ancient authors-naturalists, historians, or poets, representing the reading and filing of a whole lifetime indeed. The mention of the corresponding names in the modern Greek language is extremely accurate, except in a few cases, where Prof. D'Arcy Thompson has been led into error by foreign observers describing Greek birds. For example, the neutral in modern Greek does not use the terminal syllable ov of earlier forms (ancient Greek of Byzantine), so that the

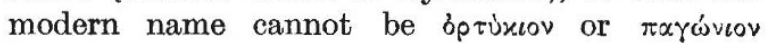

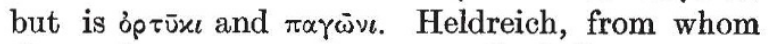
the author quotes, was a naturalized German, and was influenced by the ancient grammatical forms, or he heard the names from Greek purists who thought it probably more elegant to use classical forms instead of the popular ones, especially when informing foreigners. Such lapses, however, are rare and unimportant, and the correct forms are also mentioned by the author.

Ancient Greek literature, descriptive as well as imaginative, is luxuriously rich in its references to birds. Prof. D'Arcy Thompson borrowed lavishly from it, and I think that no quotation worthy of being referred to has been missed. Thus we have in the book a real treasure of quotations, which can be enjoyed by the naturalist as well as the scholar or the ordinary reader. Since the first edition of the book, the author has been able even to enlarge and to complete them. The whole romance of the life of Greek birds is displayed here in the etymology of their names (sometimes unknown, disputed or obscure), in epithets and phrases from authors or poets, in their description, nesting and migration, or with reference to mythical and legendary traditions connected with them. Some of the latter are really fascinating, and it is interesting to see them sometimes perpetuated to-day among the Greek people.

One of the most captivating chapters of the book is the long one devoted to the swallow, the bird of the returning spring, or as Sappho sings, 